\title{
Wind and solar energy technologies of hydrogen production - a review of issues
}

ABSTRACT: Hydrogen-based power engineering has great potential for upgrading present and future structures of heat and electricity generation and for decarbonizing industrial technologies. The production of hydrogen and its optimal utilization in the economy and transport for the achievement of ecological and economic goals requires a wide discussion of many technological and operational - related issues as well as intensive scientific research. The introductory section of the paper indicates the main functions of hydrogen in the decarbonization of power energy generation and industrial processes, and discusses selected assumptions and conditions for the implementation of development scenarios outlined by the Hydrogen Council, 2017 and IEA, 2019. The first scenario assumes an $18 \%$ share of hydrogen in final energy consumption in 2050 and the elimination $6 \mathrm{Gt}$ of carbon dioxide emissions per year. The second document was prepared in connection with the G20 summit in Japan. It presents the current state of hydrogen technology development and outlines the scenario of their development and significance, in particular until 2030. The second part of the paper presents a description of main hybrid Power-to-Power, Power-to-Gas and Power-to-Liquid technological structures with the electrolytic production of hydrogen from renewable sources. General technological diagrams of the use of water and carbon dioxide coelectrolysis in the production of fuels using F-T synthesis and the methanol production scheme are presented. Methods of inte-

$\triangle$ Corresponding Author: Tadeusz Chmielniak; e-mail: tadeusz.chmielniak@polsl.pl

1 Institute of Power Technology and Turbomachinery, Silesian University of Technology, Poland; ORCID iD: 00000001-6717-277X; e-mail: tadeusz.chmielniak@polsl.pl

2019. The Author(s). This is an open-access article distributed under the terms of the Creative Commons Attribution-ShareAlike International License (CC BY-SA 4.0, http://creativecommons.org/licenses/by-sa/4.0/), which permits use, distribution, and reproduction in any medium, provided that the Article is properly cited. 
gration of renewable energy with electrolytic hydrogen production technologies are indicated, and reliability indicators used in the selection of the principal modules of hybrid systems are discussed. A more detailed description is presented of the optimal method of obtaining a direct coupling of photovoltaic (PV) panels with electrolyzers.

KEYWORDS: hydrogen-based power engineering, development scenarios, wind and solar energy, generation of hydrogen and fuels, hybrid power system

\section{Introduction}

Hydrogen may play a fundamental role in the process of energy transformation required to limit global warming to two degrees Celsius (two-degree scenario) (Hydrogen Council, November 2017). The transformation main ecological target is to reduce energy-related carbon dioxide emissions by $60 \%$ until 2050 . Hydrogen can play many functions in the process, such as:

$\checkmark$ scaling up the utilization of renewable sources and their optimal integration in processes of electricity generation and the production of fuels,

$\downarrow$ distributing energy across sectors and regions,

$\downarrow$ acting as a buffer and a strategic reserve of power to increase the energy system resilience,

$\diamond$ decarbonizing transportation,

$\downarrow$ decarbonizing industrial technologies,

$\checkmark$ decreasing the intensity of emissions of heat and electricity generation processes in municipal services and housing,

$\downarrow$ providing clean feedstock for industry.

The scenario presented in (Hydrogen Council 2017) assumes an $18 \%$ rise in the share of hydrogen in the final energy demand in 2050, a 6 Gt abatement of annual $\mathrm{CO}_{2}$ emissions by using hydrogen-based technologies, 2.5 trillion-dollar-worth annual sales of hydrogen and hydrogen installation equipment and the creation of 30 million jobs. According to the scenario, the dynamic of scaling up hydrogen technologies will be the greatest in the years 2040-2050. Between 2015 and 2050 there will be a tenfold rise in the annual demand for hydrogen energy from 8 to $78 \mathrm{EJ}$, and between the years 2040 and 2050 a rise is envisaged from $28 \mathrm{EJ}$ to $78 \mathrm{EJ}$ (1 exajoule $(\mathrm{EJ}) \cong 277.8 \mathrm{TWh})$. The technological structure of hydrogen utilization in 2050 includes the consumption of $10 \mathrm{EJ}$ in the economy sectors where the gas is used now, $9 \mathrm{EJ}$ in new industrial process (carbon capture and utilization (CCU), direct reduced iron (DRI)), 11 EJ in municipal services and housing, $16 \mathrm{EJ}$ in industrial energy management, $22 \mathrm{EJ}$ in transportation and $9 \mathrm{EJ}$ in electricity generation processes (buffering, strategic reserve, storage). This points to considerable potential of hydrogen technologies that can be used in transportation decarbonization and industrial processes improvement. The IEA report for the G20 summit in Japan (IEA 2019) presents the current state of the hydrogen production technology and economy and outlines scenarios for potential applications of the gas, especially in the 2030-perspective. The currently 
identified challenges that will have to be tackled while scaling up hydrogen technologies are indicated. Generally speaking, the challenges include as follows:

$\downarrow$ Hydrogen production using low-carbon energy is presently rather costly. (According to the IEA analysis, the cost of hydrogen production using electricity obtained from renewable sources could fall by $30 \%$ in 2030 due to the reduction in renewable energy costs and the scaling up of hydrogen production. These factors will favor improvement in electrolysis-based technologies and the popularization of fuel cells and charging equipment).

- The development of hydrogen infrastructure is slow, which is an obstacle to the widespread application of the technology. (This affects hydrogen market prices, which depend considerably on the number of available refueling stations and the reliability of hydrogen supplies. Tackling this may require planning and coordination at international and national levels, as well as the involvement of self-governments and local authorities and of industrial institutions and private investors).

$\downarrow$ Hydrogen is now produced almost entirely from natural gas and coal. Despite technological advancement, such hydrogen production is responsible for large emissions of carbon dioxide (annual $\mathrm{CO}_{2}$ emissions total combined emissions of Indonesia and the UK). It is necessary to intensify hydrogen generation from renewable energy sources and to capture carbon dioxide from fossil fuels utilization processes. The gas has to be used in industrial technologies.

$\downarrow$ Current regulations restrict the development of the clean hydrogen industry. For example, a common international standard for the safety of transport and storage of large amounts of hydrogen has to be developed and the environmental impact of different hydrogen supply technologies has to be monitored.

To reduce the unfavorable effects, many recommendations are put forward to scale up hydrogen utilization. Firstly, it is important to determine the role of hydrogen in long-term energy and economic strategies. This concerns both national and regional policy. Companies should have well-defined long-term objectives (the key sectors are: chemistry - refining, chemicals; metallurgy - iron and steel; goods transport and long-distance transport; buildings and generation and storage of energy). Many countries have already developed such strategies. Poland, however, lacks a coherent program of long-term development concepts despite the fact that a lot is being said about the need to develop electromobility (transportation decarbonization). It is necessary to support studies, research and development works and efforts aiming to improve the technology and to reduce the costs related thereto. Well-formulated research programs and their implementation are of key significance for the improvement of the efficiency of all technological modules of the hydrogen economy (including fuel cells, generation of new hydrogen-based fuels, electrolytic production of hydrogen, mastering new technologies of production, transport, storage and utilization of hydrogen in the economy). The government actions, including the use of public funds, are of fundamental significance in the formulation of research and development programs, the implementation of research results, taking research risk and encouraging the private capital to innovate. Studies on new technologies enable a better determination of their technical and economic potential and, thereby, reduce investment and implementation risks. 
The paper presents a description of the main Power-to-Power, Power-to-Gas and Power-to -Liquid technological structures with the electrolytic production of hydrogen from renewable sources. Methods of renewable driving energy integration with electrolysis-based technologies of hydrogen generation are described. General reliability indicators and criteria of the selection of principal modules of hybrid systems are presented.

\section{General description of technological structures}

Hydrogen has a wide range of applications. The possibilities of obtaining and utilizing it in the economy are presented in Figure 1. The diagram can be used as the basis to find the optimal path of the development of hydrogen technologies (taking account of natural and renewable resources) and their utilization in the entire economy and in the power sector for assumed eco-

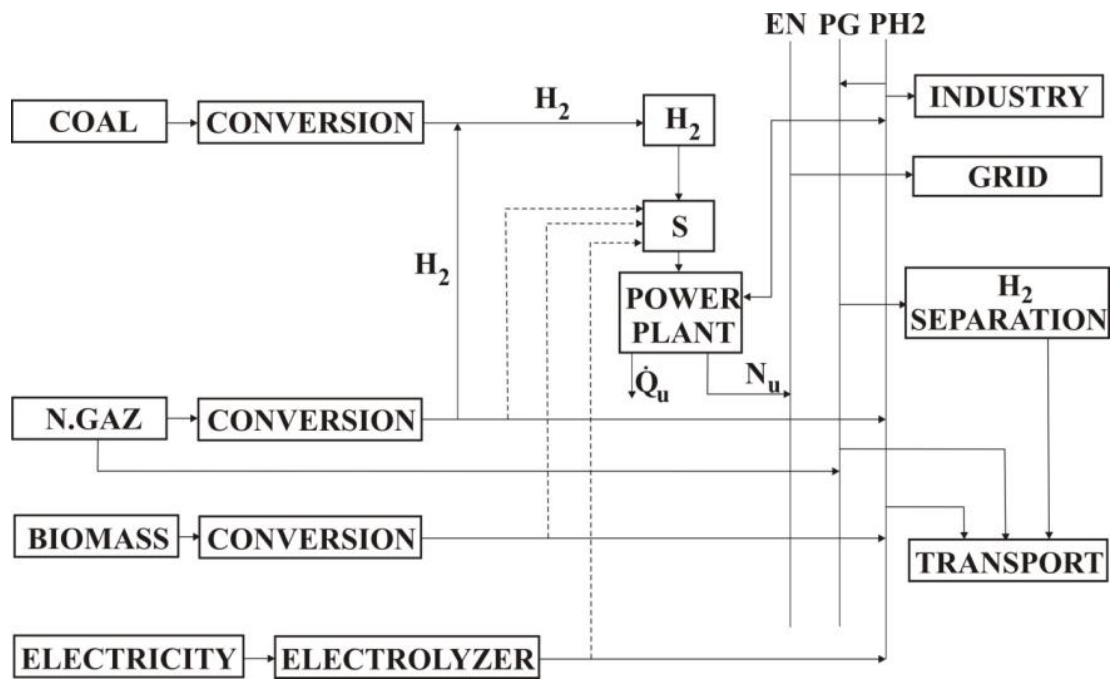

Fig. 1. General technological structure of the hydrogen production and utilization system

Rys. 1. Ogólna struktura technologiczna systemu wytwarzania i wykorzystania wodoru

nomic criteria and ecological restrictions (e.g. Qadrdan et al. 2008). It should be stressed that the use of hydrogen for energy-generation purposes cannot only be limited to paths which are characteristic of hydrogen production from renewable sources, i.e. from the:

^ Power-to-Power technology,

$\downarrow$ Power-to-Gas technology $\left(\mathrm{H}_{2}+\mathrm{CH}_{4}\right.$ mixture, methanation),

$\checkmark$ Power-to-Liquid technology. 
There are solutions for using low-emission fossil fuels (coal and gas with carbon dioxide separation) and nuclear fuels which may turn out to be competitive with technologies based on renewable sources (depending on the stage of their development).

For random driving energy (wind or solar power), the analysis of the technology effectiveness should cover the driving power generation module and its integration with hydrogen production and utilization. For biomass, geothermal energy, nuclear power engineering and fossil fuels, mutual selection of characteristics of the installation individual modules is generally less complicated.

In the general solution, the Power-to-Power path, using wind and solar power to generate driving energy through electrolysis, can include the modules shown in Figure 2. In specific solutions, the power module includes fuel cells, gas turbines (air- or oxy-combustion; fuel: hydrogen/methane mixture), internal combustion engines, Stirling engines. Depending on the kinds of sources and receivers, and also of the electrolyzer (direct current DC or alternating current $\mathrm{AC})$, the system makes use of different (DC/DC and DC/AC) converters and regulators (S). The

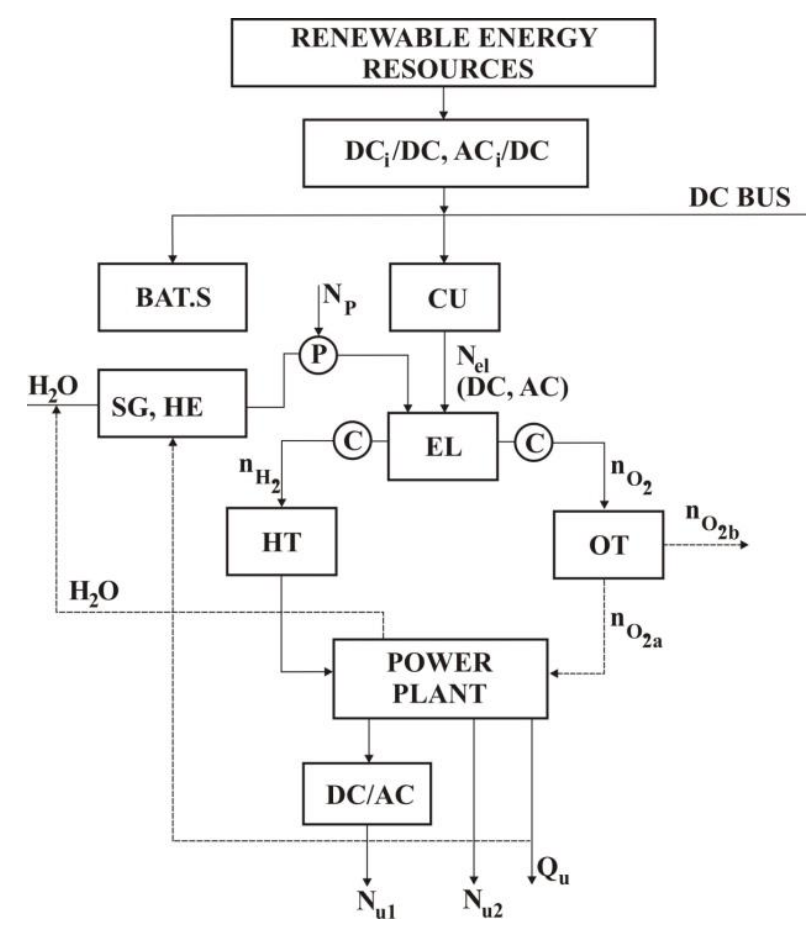

Fig. 2. General technological diagram of electrolysis integration with renewable driving energy sources for the electrolysis process; BAT.S - battery, CU - control unit, EL - electrolyzer, SG - steam generation, HE - heat exchanger, $\mathrm{C}$ - compressor, $\mathrm{P}$ - pump, HT and OT - hydrogen and oxygen tank

Rys. 2. Ogólny schemat technologiczny integracji elektrolizy z odnawialnymi napędowymi źródłami energii dla procesu elektrolizy; BAT.S - bateria, CU - moduł kontrolny, EL - elektrolizer, SG - generacja pary, HE - wymiennik ciepła, C - sprężarka, P - pompa, HT i OT - zbiornik wodoru i tlenu 
products are useful power $N_{u}$ and useful heat $Q_{u}$. Fuel-cell technologies can, in particular, be organized according to the diagrams presented in Figures 3 and 4 (Kaviani et al. 2009; Yilanci et al. 2009). The strategies will also differ depending on the installation scale and the function played in the power system. The methods used in studies on and in the testing of standalone lowcapacity dispersed power systems differ from those used in the analysis of the co-operation of large installations (e.g. wind farms) with hydrogen production technologies.

A separate group of issues is related to hybrid technologies of fuel production from hydrogen (Power-to-Gas, Power-to-Liquid). The technological solutions in this area are also very diverse (Graves et al. 2011; Schmidt and Weindorf 2016). Figure 5 illustrates diagrams with carbon dioxide partial and full recirculation. The diagram in Figure 6 concerns fuel generation using an intermediate module of methanol synthesis.

In the classical Fischer-Tropsch (F-T) process liquid fuel is produced according to the following reaction (Graves et al. 2011):

$$
2 \mathrm{H}_{2(g)}+\mathrm{CO}_{(g)} \rightarrow-\mathrm{CH}_{2}-_{(c)}+\mathrm{H}_{2} \mathrm{O}_{(g)}+165 \mathrm{~kJ}(\text { at } \mathrm{T}=400 \mathrm{~K})
$$

where:

$$
-\mathrm{CH}_{2}-{ }_{(c)}{ }^{-} \text {part of the hydrocarbon chain. }
$$

The chain length depends on the catalyst and the process temperature and pressure. At a temperature of 300-350, using iron-based catalysts, petrols and olefins with a low molar mass are obtained; in the range of 200-240 the product is diesel oil (iron- or cobalt-based catalysts). Methanol synthesis:

$$
\mathrm{CO}_{(g)}+2 \mathrm{H}_{2(g)} \rightarrow \mathrm{CH}_{3} \mathrm{OH}_{(c)}+120 \mathrm{~kJ}(298 \mathrm{~K})
$$

requires the use of catalysts from the $\mathrm{Cu}-\mathrm{ZnO} / \mathrm{Al}_{2} \mathrm{O}_{3}$ group. Other catalysts are needed for methanation (Sabatier reaction):

$$
\mathrm{CO}_{2(g)}+\mathrm{H}_{2(g)} \rightarrow \mathrm{CH}_{4(g)}+2 \mathrm{H}_{2} \mathrm{O}_{(g)}+165 \mathrm{~kJ}(298 \mathrm{~K})
$$

The process temperature is $300-400$, and the catalysts are: $\mathrm{Al}_{2} \mathrm{O}_{3}$ with an addition of $\mathrm{Ni}$ or $\mathrm{TiO}_{2}$ with an addition of $\mathrm{Ru}$.

The process of $\mathrm{CO}_{2}$ methanation is now tested on a laboratory scale and, although satisfactory effectiveness is achieved, there are still problems with maintaining the process stability (control of heat dissipation and keeping the reaction optimal temperature) (Breyer et al. 2011). The carbon dioxide needed for the synthesis can be obtained from conventional sources (flue gas separation in coal- or gas-fired power plants) or as a by-product of industrial processes. It may also be the effect of biomass fermentation and gasification, or it can be separated from atmospheric air. It should be remembered that obtaining large amounts of carbon dioxide, apart from the gas separation from fossil fuel combustion processes (which in this case is costly and energy-con- 


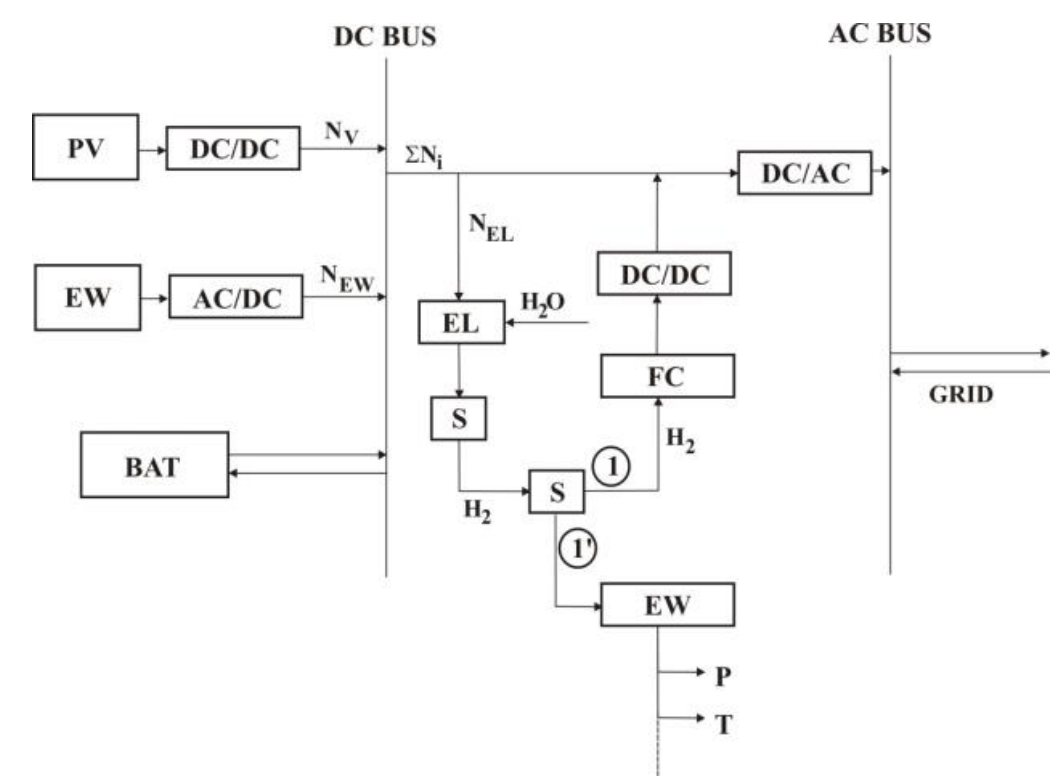

Fig. 3. A method of integration of hydrogen electrolytic generation with the network and the fuel cell Rys. 3. Jeden ze sposobów integracji elektrolitycznej generacji wodoru z siecią i ogniwem paliwowym

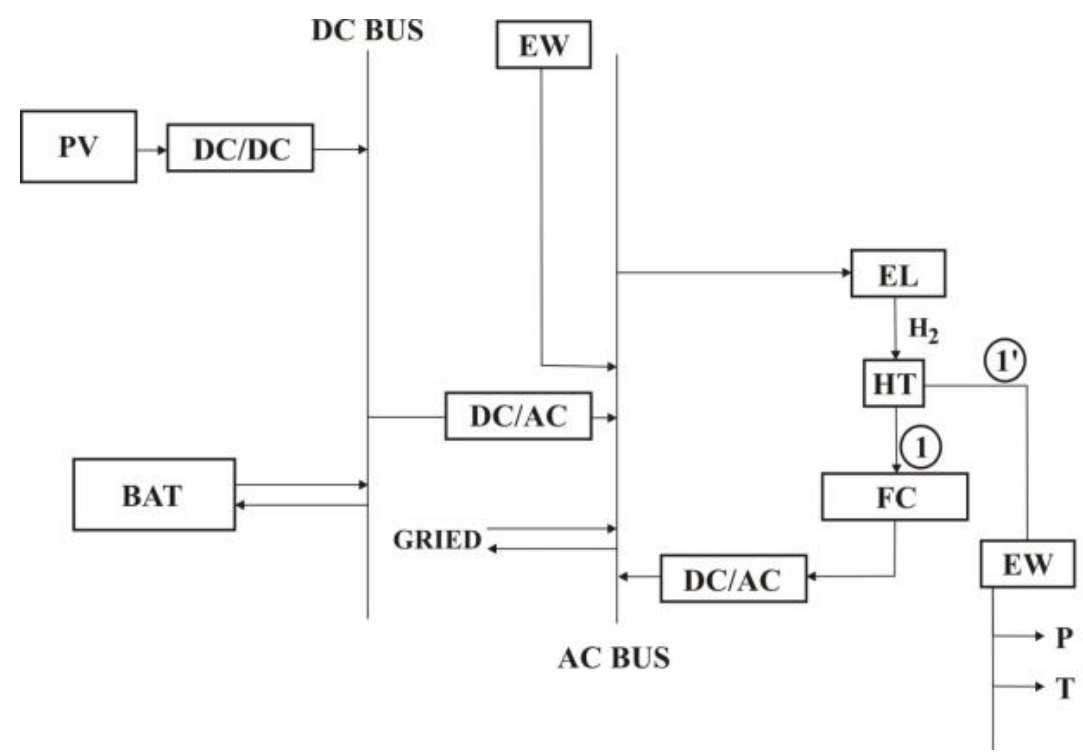

Fig. 4. Another method of integration of hydrogen electrolytic generation with the network and the fuel cell Rys. 4. Inny sposób integracji elektrolitycznej generacji wodoru z siecią i ogniwem paliwowym 

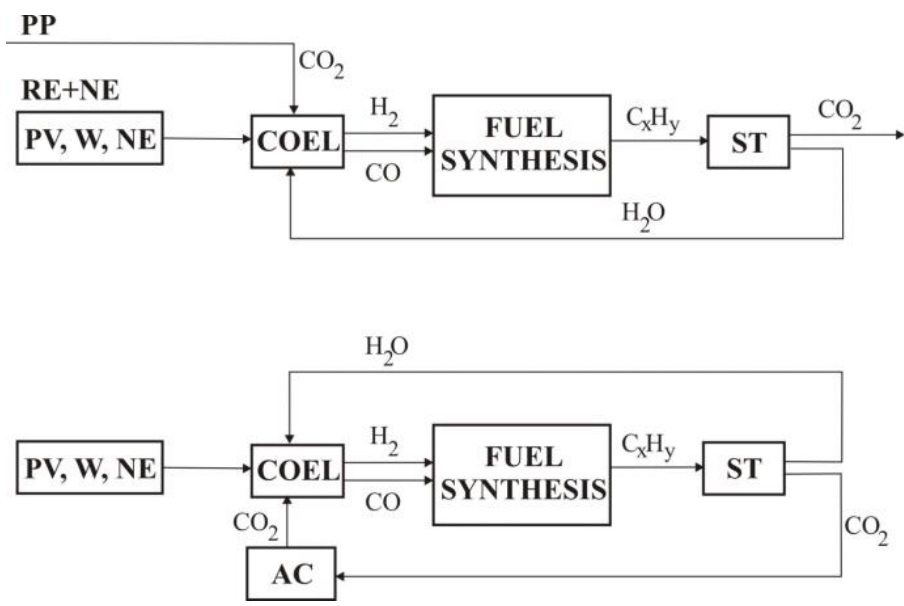

Fig. 5. Fuel generation system with co-electrolysis

$\mathrm{RE}+\mathrm{NE}-$ Renewable + Nuclear Energy, COEL - Co-elektrolysis, ST - Transport System

Rys. 5. Układ generacji paliwa z procesem koelektrolizy

$\mathrm{RE}+\mathrm{NE}-\mathrm{OZE}+$ energetyka jądrowa, COEL - koelektroliza, ST - system transportowy

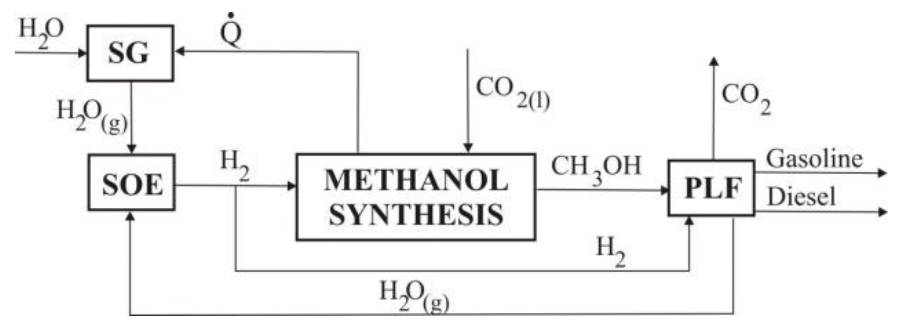

Fig. 6. Methanol generation system with co-electrolysis; SG - Steam Generation

Rys. 6. Układ generacji metanolu z procesem koelektrolizy; SG - generacja pary

suming, Ściążko and Więcław-Solny 2015) is rather difficult (low efficiency of absorption from air, limited output capacity of biogas-fired plants and biomass gasification installations). Ensuring the methanation process effectiveness requires supplies of very pure carbon dioxide and steady supplies of hydrogen. For systems using renewable driving energy, a hydrogen tank will have to be introduced into the installation to mitigate the non-stationary nature of hydrogen generation in the process of electrolysis.

Feeding methane or hydrogen generated from renewable sources into gas distribution networks enables storage of excess electricity in the form of methane and hydrogen energy. There are no reasons why the network should not be fed with synthetic methane. The introduced hydrogen amount is limited due to the change in the gas parameters which are important for consumers, especially in the power sector (combustion in gas turbines requires changes in the supply 
system and burners) (Chaczykowski and Osiadacz 2016). The limitation can also result from reasons related to materials and gas storage. These issues require further research.

The interest in methane production and in feeding the gas into the gas network has been growing lately. The number of pilot Power-to-Gas plants where hydrogen is produced from renewable sources has been rising all over the world (Gahleitner 2013). This can be especially observed in Germany, where a few projects have been completed and more demonstration plants are being planned (two more installations: one with methane synthesis and the gas use in a filling station $(250 \mathrm{~kW})$ and the other - a $6.3 \mathrm{MW}$ installation from which methane is fed into the gas distribution network).

The presented systems do not exhaust all technological opportunities.

\section{Integration of electrolytic systems of hydrogen generation with various forms of driving energy systems}

The diversity of possible technological structures presented in the previous section points to the need for finding methods of optimal integration of different component modules. The methods have to take account of the fact that solar and wind driving energy is a function of time and place. Therefore, there are no universal solutions considering the power and efficiency of the installation individual modules.

The starting point for the search for optimal solutions (usually with an economic objective function) is the knowledge of characteristics of all modules of the installation supplemented with characteristics of solar radiation and wind parameters for the location of the power installation based on hydrogen production. several methodological approaches which could be adopted for the selection of an installation operating in specific local conditions are presented below.

Direct coupling of photovoltaic (PV) panels with electrolyzers.

One of the simplest systems is the direct coupling of photovoltaic panels with the electrolyzer. But even for this simple path, several operating strategies taking account of hydrogen energy utilization can be considered. Each adopted strategy may require a different method of analysis. Below, maximization of the amount of energy transferred from panels to the electrolyzer is assumed as the primary criterion. The selection of the size of the panels for a given electrolyzer requires the knowledge of individual characteristics of the two modules. Figure 7 presents an example characteristic of a photovoltaic panel identified based on the manufacturer's data (it is one of the modules installed in the Silesian University of Technology). The bottom power chart illustrates changes in power with marked points of the maximum value for different values of solar radiation intensity. The optimal combination of the electrolyzer and the PV panels omitting $\mathrm{DC} / \mathrm{DC}$ or DC/AC inverters and the maximum power point tracker (MPPT) is possible by direct matching of the characteristics of the two modules. For an existing panel, the panel integration 
with the electrolyzer requires such a combination (of in-series and parallel connections) of the electrolyzer cells that its characteristic should coincide with (or be as close as possible to) the maximum power line. For an existing electrolyzer module, the characteristic of the PV cells is constructed by connecting an appropriate number of panels in series or in parallel (the in-series connection shifts the characteristic along the voltage axis and the parallel connection - along the current intensity axis). In the installation design process, different combinations of in-series and parallel connections can be used both for the electrolyzer cells and for the components of the modules of PV panels.
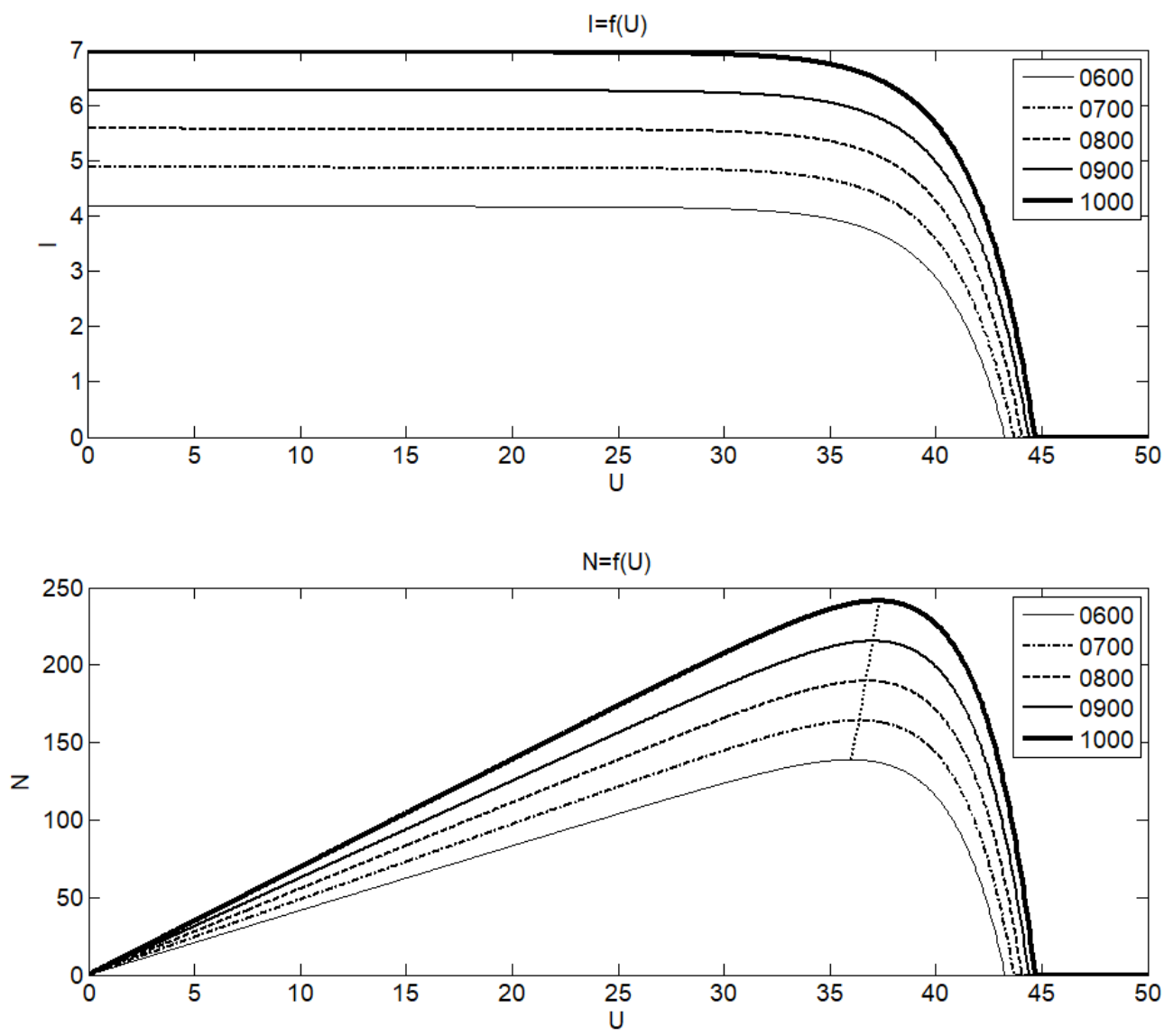

Fig. 7. Characteristics of the panel of PV cells: voltage-current curve $I=F(U)$ and power curve $N=f(U)$ for different values of solar radiation intensity $I_{c \beta}(600-1000) \mathrm{W} / \mathrm{m}^{2}$ (calculations made L. Remiorz)

Rys. 7. Charakterystyki panelu ogniw fotowoltaicznych: napięciowo-prądowa $I=F(U)$ i mocowa $N=f(U)$ dla różnych natężeń całkowitego promieniowania słonecznego $I_{c \beta}(600-1000) \mathrm{W} / \mathrm{m}^{2}$

The objective function can be minimization $\Delta \bar{E}$ for tested configurations of the panel modules and the electrolyzer cells (modules) (Paul and Andrews 2008; Clarke et al. 2009). 


$$
\Delta \bar{E}=\frac{\sum_{i=1}^{m}\left(N_{i}^{M P V}-N_{i}^{E L}\right) \cdot \Delta t_{i}}{\sum_{i-1}^{m} N_{i}^{M P V} \cdot \Delta t_{i}}
$$

where: $N_{i}^{M P V}-$ photovoltaic panel maximum power for a given value of $I_{c \beta, i}\left(I_{c \beta}-\right.$ total radiation falling on the plane inclined at the angle of $\beta$ ). $N_{i}^{E L}$ - electrolyzer actual driving power supplied from the photovoltaic panel for given values of $I_{c \beta, i}, \Delta t_{i}$ - number of hours in the analysed period of operation (typically during a year) when solar radiation intensity is included in the range of $I_{c \beta, i}-\Delta I-I_{c \beta, i}+\Delta I ; i-$ number of separated variable values of radiation $(\Delta I-$ dependent). Considering that the mass of hydrogen produced in the asssumed period of operation $\bar{m}_{H_{2}}$ can be defined as:

$$
\bar{m}_{H_{2}}=\frac{3600 l k l_{c, i} \Delta t_{i}}{1000 F} \cdot \eta_{F K}
$$

where: $l$ - number of electrolyzer cells connected in series, $k$ - number of electrolyzer cells connected in parallel, $I_{c, i}$ - working current of a single cell corresponding to radiation intensity, $I_{c \beta, i}$, $\eta_{F K}, F$ - efficiency and Faraday constant, respectively), instead of (4) an objective function can be formulated that minimizes losses in hydrogen production due to an imperfect PV panel-electrolyzer connection.

Slightly different methods of the direct coupling are presented by (Garcia-Valverde et al. 2011; Fujii et al. 2013; Zhou et al. 2008).

\section{Multi-module systems}

Many methods of the selection of characteristics of hydrogen systems of electricity and hydrogen production have been proposed. Considering the diversity of their technological structures and different operating strategies, it is difficult to pinpoint one that is universal. In the case of standalone dispersed systems, the methodologies differ from those applied to optimize installations co-operating with the high-voltage power network. Like in the analysis of other power generation structures, many (energy) availability indicators are defined. The following are used while formulating specific tasks (Garcia and Weisser 2006; Bagen and Billinton 2005; Abbes et al. 2014):

a. Loss of load expectation (LOLE)

$$
L O L E=\sum_{h=1}^{H} E[L O L(h)]
$$

$E(L O L)=\sum_{s \in S} T(s) \times p(s), p(s)$ is the probability of the occurrence of state $s$ belonging to set $S$ of all possible states, $T(s)$ - the number of hours of breaks of power supply with occurrence probability $p(s)$. Assuming that $H$ is the number of hours in the year, LOLE (h/year) is the number 
of hours during a year with probability $p(s)$ of the occurrence of breaks in energy supplies due to the loss of available power.

b. Expected energy not supplied (EENS)

$$
L O E E=E E N S=\sum_{h=1}^{H} E[L O E](h)
$$

$E(L O E)=\sum_{s \in S} Q(s) \times p(s), Q(s)-$ amount of energy not supplied (kWh) if state $s$ occurs.

EENS is the basis to determine all reliability measures. It defines the amount of energy not supplied due to insufficient available power.

c. Loss of power supply probability (LPSP)

$$
L P S P=\frac{L O E E}{\sum_{h=1}^{H} D(h)}
$$

$D(h)$ - demand for energy for a given time period $h$.

d. Equivalent loss factor (ELF)

$$
E L F=\frac{1}{2} \sum_{h=1}^{H} \frac{E[Q(h)]}{D(h)}
$$

The required values of different reliability measures and their mutual relations are discussed, among others, in the EU report Identification of Appropriate Generation and System Adequacy Standards for the Internal Electricity Market (Final Report EUR 2015.1392EN, AF Mercados, E-Bridge, REF-E, 20 March 2016). All the presented measures are used in formulated optimization tasks, with the last two prevailing. The simplest methodological approach is to minimize costs keeping the desired value of one reliability ore ecological measure (Palej et al. 2019 ). In more advanced analyses, multi-objective optimization is considered. Abbes et al. (2014) formulate the task of cost minimization in the entire life cycle of all modules of the system, LPSP minimization and minimization of cumulated consumption of energy in the process of making the system elements. The last requirement corresponds to minimization of the burden on the natural environment. In specific tasks some other measures can also be used which supplement the above measures (5-8). Sometimes the measures are defined differently (Kaabeche at al. 2011). In systems with large driving units the objective function is often defined in economic categories (Peng Hou et al. 2017; Jiang et al. 2019). 


\section{Concluding remarks}

Hydrogen-based power engineering has great potential for upgrading present and future structures of heat and electricity generation and industrial technologies. This is mainly due to the possibility of using renewable energy sources in hydrogen generation technologies, many proven methods of energy storage in hydrogen and the possibility of zero-emission utilization of hydrogen in various power and industrial plants and in transportation. However, further ventures are needed aiming to improve electrolyzers and other methods of hydrogen production. It is important to find optimal systems of hydrogen utilization and hydrogen storage. A lot of attention has to be devoted to the selection of methods of integrating modules which are characteristic of the Power-to-Power, Power-to-Gas and Power-to-Liquid paths. Considering that rational hydrogen -based power generation depends largely on the local potential of renewable sources (but also on the energy mix in the power sector and transportation), it becomes necessary to prepare a national programs of hydrogen-based power engineering development. Many countries have already developed appropriate strategies in this area to become the basis for research and development programs. It is necessary to select directions of investment into pilot and demonstration installations. In terms of research, the following can be considered topical for the conditions in Poland:

$\checkmark$ Identification of research carried out on various issues of hydrogen-based power engineering in Poland and an attempt to coordinate the efforts, including formulation of plans for pilot plant construction).

$\checkmark$ Development of assumptions of a research program covering issues with great potential for application in the Polish conditions.

$\checkmark$ Parallel studies on the role of hydrogen in decarbonization of transportation (production of liquid fuels, fuel cells in transport) and power engineering (systems coupled with fuel cells, gas turbines, integration of solar and wind power engineering with hydrogen production technologies, biomass technologies, the role of fossil fuels in the development of hydrogen-based power generation), and on the possibility and functionality of methanation to supply gas distribution networks.

\section{References}

ABBes et al. 2014 - ABBes, D., MARTines, A. and Champenois, G. 2014. Life cycle cost, embodied energy loss of power supply probability for the optimal design of hybrid power systems. Mathematics and Computers in Simulation 98, pp. 46-62.

Bagen, A. and Billinton, R. 2005. Evaluation of Different Operating Strategies in Small Standalone Power Systems. IEEE Transactions on Energy conversion Vol. 20, No. 3, September.

BREYER et al. 2011 - BREYER, C.H., RIEKE, S., STERNER, M. and SCHMID, J. 2011. Hybrid PV-wind-renewable methane power plants. [In:] European Photovoltaic Solar Energy Conference, Hamburg, Germany. [Online] <http://www.q-cells.com/uploads/tx_abdownloads/files/6CV.1.31_Breyer2011_HybPV -Wind-RPM-Plants_paper_PVSEC_preprint.pdf>; 2011 [Accessed: 2012-08-27]. 
ChaczYKowski, M. and Osiadacz, A.J. 2016. Power-to-Gas technology in terms of co-operation with the gas power system (Technologia Power-to-Gas w aspekcie wspólpracy $z$ systemem gazowniczym). $6^{\text {th }}$ Science and Technology Conference "Gas Power Engineering 2016".

Clarke et al. 2009 - Clarke, R., Giddey, E.S., CiACCHI, F.T., BAdwAL, S.P.C., Paul, B. and ANDrews, J. 2009. Direct coupling of an electrolyzer to a solar PV system for generating hydrogen. International Journal of Hydrogen Energy 34, pp. 2531-2542.

FUJII et al. 2013 - FUJII, K., NAKAMURA, S. and SUgIYAMA, M. 2013. Characteristic of hydrogen generation from water splitting by polymer electrolyte electrochemical cell directly connected with concentrated photovoltaic cell. International Journal of Hydrogen Energy 38, pp. 14424-14432.

GAHLEITNER, G. 2013. Hydrogen from renewable electricity: An international review of power-to-gas pilot plants for stationary applications. International Journal of Hydrogen Energy 38, pp. 2039-61.

GARCIA-VALVERDE et al. 2011 - GARCIA-VALVERDE, R., EsPinOSA, N. and Urbina, A. 2011. Optimized method for photovoltaic-water electrolyzer direct coupling. International Journal of Hydrogen Energy 36, pp. 10574-10586.

GARCIA, R.S. and WEISSER, D. 2006. A wind-diesel system with hydrogen storage: Joint optimisation of design and dispatch. Renewable Energy 31, pp. 2296-2320.

Graves et al. 2011 - GraVes, Ch., Ebbesen, S.D., Mogensen, M. and LaCKNER, K.S. 2011. Sustainable hydrogen fuels by recycling $\mathrm{CO}_{2}$ and $\mathrm{H}_{2} \mathrm{O}$ with renewable or nuclear energy. Renewable and Sustainable Energy Reviews 15, pp. 1-23.

Hydrogen scaling up. A sustainable pathway for the global energy transition. Hydrogen Council, November 2017.

Identification of Appropriate Generation and System Adequacy Standards for the Internal Electricity Market 2016 (Final Report EUR 2015.1392EN, AF Mercados, E-Bridge, REF-E, 20 March 2016).

JIANG et al. 2019 - JIANG, Y.Z., DENG, Z. and YOU, S. 2019. Size optimization and economic analysis of a coupled wind-hydrogen system with curtailment decisions. International Journal of Hydrogen Energy 44, pp. 19658-19666.

KAABECHE et al. 2011 - KAABeche, A., Belhamel, M. and IbTiouen, R. 2011. Techno-economic valuation and optimization of integrated photovoltaic/wind energy conversion system. Solar Energy 85, pp. 2407-2420.

KAVIANI et al. 2009 - KAVIANI, K.A., RIAHY, G.H. and KOUHSARI, SH.M. 2009. Optimal design of reliable hydrogen-based standalone wind/PV generating system, considering component outages. Renewable Energy 34, pp. 2380-2390.

PaleJ et al. 2019 - PaleJ, P., Qusay, H., Kleszcz, S., Hanus R. and Jaszczur, M. 2019. Analysis and optimization of hybrid renewable energy systems. Polityka Energetyczna - Energy Policy Journal Vol. 22, Iss. 2, pp. 107-120.

PAUL, B. and ANDREwS, J. 2008. Optimal coupling of PV arrays to PM electrolyzers in solar-hydrogen systems for remote area power supply. International Journal of Hydrogen Energy 33, pp. 490-498.

PENG Hou, et al. 2017. Optimizing investments in coupled offshore wind-electrolytic hydrogen storage systems in Denmark. Journal of Power Sources 359, pp. 186-197.

QADRDAN et al. 2008 - QADRDAN, M., SABOOHI,Y. and SHAYEGAN, J. 2008. A model for investigation of optimal hydrogen pathway, and evaluation of environmental impacts of hydrogen supply system. International Journal of Hydrogen Energy 33, pp. 7314-7325.

SCHMIDT, P.R. and WEINDORF, W. 2016. Kraftstoffe der Zukunft in der Luftfahrt - Strom tanken mit Power -to-liquids. Bodensee Aerospace Meeting, Uberlingen, 01.03.2016.

The Future of Hydrogen, IEA, June 2019.

YILANCI et al. 2009 - YILANCI, A., DinCER, I. and OzTURK, H.K. 2009. A review on solar-hydrogen/fuel cell hybrid energy systems for stationary applications. Progress I Energy and Combustion Science 35, pp. 231-241. 
Zhou et al. 2008 - Zhou, K. Ferreira, J.A. and DE HAAN, S.W.H. 2008. Optimal energy management strategy and system sizing method for standalone photovoltaic-hydrogen systems. International Journal of Hydrogen Energy 33, pp. 477-489.

Tadeusz CHMIELNIAK

\title{
Technologie wytwarzania wodoru z wykorzystaniem energii wiatru i słońca. Przegląd zagadnień
}

\begin{abstract}
Streszczenie
Technologie energetyki wodorowej mają duży potencjał dla unowocześnienia obecnych i przyszłych struktur wytwarzania energii elektrycznej, ciepła i dla dekarbonizacji technologii przemysłowych. Wytwarzanie wodoru i jego optymalne wykorzystanie w gospodarce i transporcie dla osiągnięcia celów ekologicznych i ekonomicznych wymaga dyskusji wielu zagadnień technologicznych i eksploatacyjnych oraz intensywnych badań naukowych. W części wstępnej artykułu wskazano na główne funkcje wodoru w osiągnięciu dekarbonizacji energetyki i procesów przemysłowych oraz omówiono wybrane założenia i warunki realizacji scenariuszy rozwojowych Hydrogen Council, 2017 i IEA, 2019. Pierwszy scenariusz zakłada $18 \%$ udział wodoru w finalnym zużyciu energii w 2050 i eliminację $6 \mathrm{Gt}$ emisji ditlenku wegla rocznie. Drugi dokument został przygotowany w związku ze szczytem G20 w Japonii. Przedstawia on współczesny stan rozwoju technologii wodorowych oraz nakreśla scenariusz ich rozwoju i znaczenia, w szczególności w perspektywie do 2030 r. W drugiej części artykułu przedstawiono charakterystykę głównych hybrydowych struktur technologicznych Power-to-Power, Power-to-Gas i Power-to-Liquid z elektrolitycznym wytwarzaniem wodoru ze źródeł odnawialnych. Przedstawiono schematy technologiczne wykorzystania koelektrolizy wody i ditlenku węgla w produkcji paliw z wykorzystaniem syntezy F-T i schemat produkcji metanolu. Wskazano na sposoby integracji odnawialnej energii napędowej z elektrolitycznymi technologiami wytwarzania wodoru i omówiono wskaźniki niezawodności wykorzystywane w doborze głównych modułów układów hybrydowych. Szczegółowiej przedstawiono optymalny sposób uzyskania bezpośredniego połączenia paneli ogniw fotowoltaicznych i elektrolizerów.
\end{abstract}

SŁOWA KLUCZOWE: energetyka wodorowa, scenariusze rozwoju, energetyka wiatrowa i słoneczna, wytwarzanie wodoru i paliw, energetyczne układy hybrydowe 
